\title{
208 破裂性弓部大動脈瘤に対する手術と補助手段
}

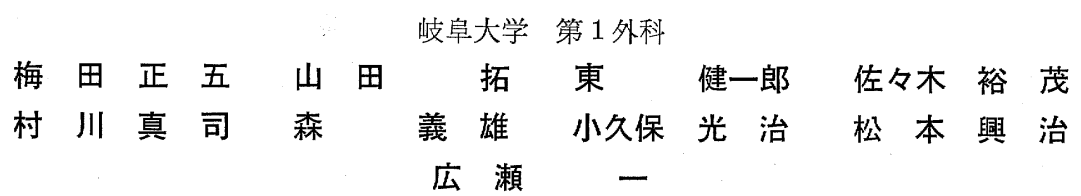

弓部大動脈瘤の外科治療は，補助手段が他の胸部大動 脈瘤手術に比して, 複雑であり, しか子破裂例に対して は未だ満足する成績が得られていない，われわれは連続 する 4 例の破裂性弓部大動脈瘤の治療に対し, 緊急手術 を施行した。補助手段として, 脳保護の目的に脳分離体 外循環 (以下 SCP), 手術操作の簡易化の目的に，われ われが考案した順行性に挿入可能なカテーテル部を鋼線 にて補強した大動脈閉塞用バルーン・カテーテル（以下 $\mathrm{AOBC})^{1)}$ を用いたのでここに報告する.

\section{対象・方法}

1988 年 4 月より 1989 年 12 月までの約 20 か月間に, 真性胸部大動脈瘤を 14 例経験し, 弓部大動脈瘤は 5 例 で, このうち 4 例は破裂性弓部大動脈瘤であった（表 1). 年齢は 70〜 74 歳 (平均 72 歳) で，いずれも緊急 手術を施行した。

内訳は真性大動脈瘤の綐隔内破裂 1 例, 真性大動脈瘤 に隣接した仮性大動脈瘤の左肺内破裂 1 例, 真性大動脈 瘤手術 6 年後の吻合部仮性大動脈瘤の左肺内破裂 1 例, 真性大動脈瘤の左肺内および綐隔内破裂 1 例であり，4 例中 3 例が左肺内破裂を認めた（表 2 ）。

手術手技は 4 症例ともに同様であり，まず到達方法は 胸骨縦切開に，左鎖骨上窩への斜切開を加え，左胸腔は 開いていない，胸骨縦切開後は，胸骨の離開を最小限に とどめた視野で，極力，大動脈には触れるととなく，心 膜縦切開を行い，脱血管择入用に，右房にたばこ囊縫合
をかけた，送血は左大腿動脈，脱血は右房を通じて上下 大静脈より行い，体外循環を行った，直腸温 $20^{\circ} \mathrm{C}$ を目 標に core cooling を行い, その間に腕頭動脈, 左総頸 動脈に送血管を挿入し，2台別々のポンプで送血し， SCP とした. 心筋保謢には, 冷却心筋保護液に ice slush による topical cooling を併用した。

次に左大腿動脈より送血を一時中断し， $\mathrm{AOBC}$ を大 動脈瘤より 健常な弓部大動脈前壁へ延長した切開口よ り，大動脈側に順行性に插入し，下行大動脈でバルーン を inflate させ末梢側大動脈の遮断を行った. 大動脈瘤 に対しては，2例に囊状動脈瘤入口部を人工血管によっ てパッチ閉鎖, 残る 2 例は動脈瘤切除後人工血管にて置 換し，乙のうち 1 例に腕頭，左総頸動脈の再建を行った (表 2 ).

結果

手術死亡は 1例で, 症例 4 すなわち弓部大動脈置換術 および上行大動脈から腕頭，左総頸動脈への人工血管に よる血行再建を施行した症例である。乙れは冠動脈器質 的病変を伴っており，術中心筋梗塞症を合併し，体外循 環より離脱できないまま失った，剖検所見では，LAD に著明な石灰化を認め，ほぼ完全閉塞であった。ささに $4 \mathrm{PD}$ に手同様の所見を認めた. その他 3 症例の平均体 外循環時間は 138 分，平均大動脈遮断時間 61 分，平均 $\mathrm{SCP}$ 時間 52 分であり，脳合併症は 1 例す認めていな いまた術後の肝・腎機能において子すべて正常範囲内

表 1 真性胸部大動脈溜

\begin{tabular}{|c|c|c|c|}
\hline \multirow{2}{*}{ Location } & Rupture & Non rupture & Total \\
\hline & Op. death/cases & Op. death/cases & Op. death/cases \\
\hline Arch & $1 / 4$ & $0 / 1$ & $1 / 5(20 \%)$ \\
\hline Descending & $1 / 1$ & $0 / 5$ & $1 / 6(16 \%)$ \\
\hline Thoracoabdominal & $0 / 1$ & $1 / 2$ & $1 / 3(33 \%)$ \\
\hline Total & $2 / 6(33 \%)$ & $1 / 8(12.5 \%)$ & $3 / 14(21 \%)$ \\
\hline
\end{tabular}


表 2 破裂性弓部大動脈瘤の 4 症例

1. Age Sex Lesion Location of Hematoma

表 3 脳分離体外循環

\begin{tabular}{lccccc}
\hline \multicolumn{1}{c}{ Case } & 1 & 2 & 3 & Mean & 4 \\
\hline Total ECC time (min) & 120 & 174 & 119 & 138 & 360 \\
Aortic cross clamp time (min) & 35 & 87 & 60 & 61 & 80 \\
SCP time (min) & 30 & 79 & 47 & 52 & 151 \\
Innominate artery flow (ml/min) & $450-760$ & $300-400$ & $450-570$ & $400-576$ & $450-700$ \\
Left common carotid artery flow (ml/min) & $200-300$ & $250-300$ & $140-180$ & $196-260$ & $200-300$ \\
Rectal temperature ( ${ }^{\circ} \mathrm{C}$ ) & 23.4 & 20.8 & 22.0 & 22.0 & 24.4 \\
Complication & & & & & \\
$\quad$ Brain & - & - & - & & \\
$\quad$ Liver & - & - & - & & \\
$\quad$ Kidney & - & - & - &
\end{tabular}

岐皋大学第 1 外科

であった(表 3 ).

$$
\text { 考案 }
$$

破裂性弓部大動脈瘤の外科治療においては，脳保護上 迅速な対応を必要とするため手術術式の簡易化が要求さ れる.そこで脳保護には最近確立されてきた SCP を用 いた．後者の目的には左側開胸を必要とせず，さらに末 梢側大動脈の遮断を省略する方法すなわち open distal 法 ${ }^{2}$ あるいは·AOBC 法3) が報告されており，とくに本 報告例のごとく，肺内破裂が多いととからこれらの方法 は有利である. しかし，open distal 法は手技的に特別 な器具を用いない点において優れている.
しかしながら破裂症例に执いては本報告のごとく，平 均年齢 72 歳己高齡者が多いため各臟器の予備能が不良 である症例が多いてと,さらに術前ショック状態に陥っ ているととが多いとと, 術前の腹部臟器の機能が不明 であることなどから，下行大動脈が容易に遮断できる AOBC 法が優れていると考えられる. さらに従来から 市販されている逆行性 $\mathrm{AOBC}$ では，送血側と反対側の 大腿動脈の剝離を要すること, さらには大腿動脈からの $\mathrm{AOBC}$ 㨂入不能例があることなどの欠点を有している. そこでてれらの長所をいかし，欠点を補う目的で，同 一術野から㨂入可能で挿入不能例はほとんざないと考え られる順行性に插入可能な $\mathrm{AOBC}^{11}$ を考案して用い 
た．これを用いることにより 4 例中 3 例の肺内破裂例に おいてあ左胸膜腔剝離を必要之せず，手術的には比較的 迅速に対応ができた。

さらに手術操作中に肝・腎への血流が保たれるため, 術後急性期における肝・腎などの腹部臟器の機能障害の 合併症はなく手術成績屯向上した。

一方, 乙の順行性 $\mathrm{AOBC}$ 法の欠点は, カテーテルが 手術操作を妨げることである. しかし慣れるにつれて， 問題は少なくなると予想される.

しかしながら冠動脈器質病変のために術中心筋梗塞に て1例を失っている. 報告した症例にもみられるごと く, 瘤む動脈硬化症であり, 冠動脈器質的病変を伴う症 例が予測される，DeBakey らの諸家 ${ }^{4 \sim 6)}$ の報告による と, 胸部大動脈瘤での冠動脈病変合併の頻度は 16 30 \%である，しかし，破裂性弓部大動脈瘤では，緊急手術 を余儀なくされ，術前冠動脈造影等の諸検査を施行する ことは困難である．したがって，今後その䛦断と治療法
の確立が課題である.

\section{結語}

1） 4 例の連続する破裂性弓部大動脈瘤において手術 死亡を 1 例経験した.

2） 3 例の肺内破裂例に対して古順行性 $\mathrm{AOBC}$ は手 術手技上有利であった．また術後急性期の腹部臟器すな わち肝・腎機能障害を認めなかった。

3）手術死亡の 1 例は合併していた冠動脈病変による 術中心筋梗塞にて失った. 今後緊急手術症例における冠 動脈病変の術中検索手段の開発が必要と考えられる.

文 献 1) 広瀬一ほ加：日胸外会誌 $36: 5,719,1989$. 2) Cooley, D. A. et al. : Cardiovasc. Dis. (Bull. Texas Heart Inst.) $8: 421,1981$. 3) Hirose, et al. : Am. Thorac. Surg. 39: 538, 1985. 4) DeBakey, M. E. et al. : J. Cardiovasc. Surg. 19: 571, 1978. 5) Joyce, J.W. et al. : Circulation 29: 176, 1964.6) 数井睴久ほ 1984. 